Advances in Social Science, Education and Humanities Research (ASSEHR), volume 81

1st International Conference on Social and Political Development (ICOSOP 2016)

\title{
Social Protection For Child Labor
}

\author{
Nunung Nurwati \\ Department of Social Welfare \\ Faculty of Social and Political Sciences \\ University Of Padjadjaran, Bandung Indonesia \\ nngnurwati@yahoo.co.id
}

\begin{abstract}
The issue of child labor is still a concern of the Indonesian government, this is evidenced by the participation of the Indonesian government to ratify child protection, which is implemented in the form of social protection for child labor. The protection form includes a school operational costs (BOS) program, social insurance (BPJS), Package A and Package B. The programs in the area are carried out by the relevant agencies such as the provision of BOS and learning packages (package A and B) conducted by the Department of Education, BPJS by the Department of Health and the Employment Act that restricts the age and the type of work, to which the child labor has entered, done by the Department of child Labor. The implementation of these programs does not seem to be coordinated and integrated, the practices are carried out by each of institutions / agencies, so that there are many child labor who do not get the social protection. This paper aims to reveal how the implementation of protection for child workers and how the socio-economic conditions of their family. The data used comes from secondary data that has been published in the Central Bureau of Statistics (BPS), as well as primary data. Implementation of social protection for child labor is still not optimal, that there are still many child parents of workers who do not receive support from the government. This is due to the ignorance of the parents of child labors' and the society, as well as the ineffectiveness in implementing protection programs. The ignorance of parents to their social protection is due to their socio-economic backgrounds, which generally comes from low economy (poor) and low education. In addition, the people are less concerned about child labor around their homes. Communities assume that children who become employees is a family affair, and the government is still less doing further guidance for those who had already received assistance. Implementing social protection should be done in an integrated manner, so that each element (family, community and government or NGO) take its suitable share in accordance with the role and authority.
\end{abstract}

Keywords: Social protection, Child labor, Indonesia.

\section{INTRODUCTION}

The phenomenon of child labor is still there both in Indonesia and in other countries. Children who become employed worker or is already in violation of the rights of children, where the rights of children, among others; the right to protection, the right to education, health, the right to play, these rights are covered in the Convention on Child Rights, which Indonesia ratified and applied in the form of the Law on Child Protection and programs of social protection for children including child labor.

Based on the concept of the Central Bureau of Statistics (Badan Pusat Statistik) Indonesia is meant by child labor are those aged 10-14 years and was working at least one hour during the past week. In Indonesia, in 2015 there are 1.7 million child workers, 400,000 of them were forced to work for jobs worst and dangerous (ILO - BPS 2015).).

In poor countries child labor is not an option taken by the child, but a child in choosing powerlessness. This means that they 
are forced to work to earn income due to socioeconomic conditions that drive their work. Another thing her in developed countries, children who work aimed at training capabilities and independence of children's social and performed on their child himself, and carried out during the school holidays, only done in places that do not harm, for example the bookstore, the week only do no more than 3 hours. These children come from families established in terms of family income.

Children who enter the labor market must be influenced by several factors, including poverty, there are employment opportunities easily accessible by children. However, there Are Some experts who found that child labor does not always come from poor family, it has been demonstrated from studies that have been done by Bhalotra and Heady (2003) in his study in Peru and Pakistan, found that the number of children who work will increase along with the amount of land owned by the household or family. The findings have been opposed to the hypothesis of working children due to poverty, because the study that poverty is not the dominant factor will be the workers' cause.

Child labor will be a problem, when they worked long hours, thereby disrupting the learning time and go to school, so susceptible to drop out, and violates the results of ILO Conventions which Indonesia has ratified the, and violating Law No. 23 of 2002 on the protection Child. However eliminate child labor appears to be less prudent, because the existence of child labor for poor families can preserve the viability of the family.

Social protection is one form of tackling child labor. Social protection for child workers is a condition for creating a child's welfare is the fulfillment of the needs of children. According to Adesina (2010) implementation is able through social assistance to children, families and communities. This paper discusses how the implementation of social protection for child workers in small industrial sector in Cirebon Regency, Province of West Java.

\section{MATERIALS AND METHODS}

This study used qualitative methods, the reason the issues to be examined is a social problem and dynamic, requiring deep excavation associated with the implementation of social protection for working children.

\section{A. Technique of Data collection}

The technique used for data collection is done by:

1. observation, with the aim to obtain a picture related to the implementation of social protection for working children

2. The in-depth interviews, devoted to the informant who elected

3. 3. Searches related documents

B. Mechanical determination Informants

Informants in this study are all involved in the implementation of social protection of children which is derived from the Department of Employment, Education, Social Services. Of each department were selected purposively, with the consideration that the person who made the informants know the child and social protection policies can provide the necessary information in the study.

\section{Analysis of Data}

Before the data analyzed do validation of information by source triangulation of data or information in order to obtain adequate data or information as the basis for data analysis.

\section{RESULT AND DISCUSSION}

Condition of children in the study area the majority come from poor families or poor work their parents farm laborers or working odd jobs with erratic income, therefore, in the families of all members of both families, including children should be involved in doing the work. These conditions are no other options for them are forced to work by reason of petrified parents in food sufficiency. Poverty parents become the most important factors causing child labor. 
Approximately 80.6 per cent of working children no longer attending school, they only went to school until graduating elementary school, while child labor, which until this study is still a school is only 19.4 percent. According to Suyanto (2003), children are not in school or drop out tend to enter the working world. Average hours worked 7.72 hours per day, they work for 5 days a week, so they are their right to play is not met, because the time to play spent at work. According to Law No. 13 of 2003, article 69, paragraph 1 , of working children should not be more than 3 hours a day and must not do work that can harm child development. But the facts on the ground show the child workers work longer and do a job that often endanger the safety or health. Child labor in this study the majority of work in the food processing industry-drinks, many of those who work part risky accidents, for example in jelly food industrial, their daily work by standing on the floor slippery with water, if not careful, they can fall and injury.

If we referring to the convention of children's rights, that is, if work cannot be longer than 3 hours / day, to do when the school holidays, should not disrupt the school day, should not interfere with development of the child, and may not work risky or dangerous, it seems businesses are has hired a child with no regard to the CRC, as well as Law No. 13 of 2003 it is considered to have taken away the rights of children and violating the Act.

The average wage they receive Rp. 50,000 per week. In which they work, are not provided health services and lunch, so the tangible physical condition they appear less healthy. However, they survived to continue to work, for those with a wage of it, enough for him to help the family economy in fulfilling the food needs of the family.

There are some children who says they want to work (because the pay is attractive or because the child does not like school), it remains the case that undesirable because it does not guarantee the future of the child. The use of young children as workers are now considered by wealthy countries as a violation of human rights, and forbid it, but poor countries still allow for families often rely on their jobs to survive and sometimes the only source of income.

The problem of child labor cannot be separated by the efforts of child welfare is regulated in Law No. 4 of 1979 on Child Welfare, namely Law No. 4 of 1979, as described in Article I, aims at creating a system of life and livelihood of children who can ensure the growth and development of children with a reasonable, well spiritually, physically, and socially. Therefore children should be given special protection in order to protect from things that can endanger their welfare.

Child protection issues as workers are not regulated in the formulation of the law on child welfare. Only if we look at the issue of child labor within the framework of the protection of children, it will be found that child labor as a matter of conflict with this law. For example, Article 2 (4) which formulates that children have the right to protection of the environment that may harm or inhibit the growth and development of the fair. This formula relates era! with the concept of the protection of children as workers. In many places, children who work will always be in unfavorable conditions and exploited. Likewise with the condition, the work may endanger or hinder the growth and development of natural causes.

In Indonesia also has a specific law to protect the rights of children, namely Law No. 23 of 2002 on Child Protection. The law on child protection was set in 2002, twelve years after Indonesia ratified the convention states the rights of children. From the length of the time span is seen less serious the government to actually make the protection of children's rights. Article 2 states that child protection aims to ensure the fulfillment of children's rights in order to live, grow, develop and participate optimally in accordance with human dignity, as well as protection from violence and discrimination, in order to realize quality of Indonesian children, noble, and prosper, then Article 20 obliges the state, the government, communities, families and parents to take responsibility for the protection of children. Another part of this legislation formulate criminal sanctions for perpetrators of 
exploitation of children, including those who know their exploitation. The articles in this law is closely related to the formulation of a child protection worker. Especially with regard worst types of work for children as it was intended in the ILO Convention No. 182. with the criminal provisions in this law, the protection of children, especially in terms of children as workers, is expected to be implemented. Indeed, this law does not specifically regulate the protection of children as workers. But the provisions of ILO Convention No. 138 and ILO Conventions 182 has been used as the legal basis for the existence of this law.

Social protection, intended to prevent and manage the risk of shocks and the vulnerability of a person's social, family, group or community in order to function socially so that they can live naturally. Social assistance is temporary and sustainable in shape; a). Direct assistance b). The provision of accessibility and $c$ ). Institutional arrangements.

Referring to the framework Chambers (2000: 131), to see the results of the implementation of social protection should consider several things namely; First, the feasibility of legislation. Facts on the ground indicate the implementation or execution of social protection for child workers have not shown optimal results, it is proved to be right on target, less executive power as well as lack of budget, these factors led to the implementation of social protection less optimal. In determine targets child workers should receive assistance, not based on the result of the assessment, but on the basis of proximity and ease to find child labor. The field findings show that there are child laborers who have poor parents do not get help, but they deserve to be helped.

Second, related to the implementation of social protection purlu seen how much of an impact on the implementation of such protection against the number of children protected social rights. It seems that child labor is still not protected social rights, social rights such as play and interact with one another, since most of the time they spend at work.

Third, if the condition of children experienced a change for the better than the previous situation, it suggests positive impact that the implementation of social protection, otherwise if his condition does not change even worse, then the implementation of social protection can be said to be successful. The field findings show that the living conditions of child labor has not changed despite some social protection, even those who are still in school are particularly vulnerable drop out, this is because child labor concentration difficulties to follow the lessons in school, in addition, they are also learning difficulties and complete the work school. After work they already feel tired so cannot concentrate on completing school assignments, resulting in the school they are often sleepy and achievement in school down. This makes the child feel ashamed of his friends, because they feel embarrassed, they are often absent or not go to school and edges out of school (drop outs).

Referring to the opinion of Adesina (2010), one of the forms of social protection are social assistance for children. Help for children in the form of education, one for the emergence of the workers are dropping out of school (drop outs). Aid in the form of education by the government or non-government, the goal is child labor or children dropping out of school. As for the implementation of the assistance carried out by the Department of Education, for the provision of non-formal education programs such as the Equality Package A equivalent to primary education, and the equivalent of junior high schools, and $\mathrm{C}$ is equivalent to high school. The target is children aged under 15 years and under. The purpose of this program is to improve the literacy rate and given away for free. This activity is funded from APBD. In implementing the equality program package Department of Education in collaboration with civil society organizations in the area.

The results of interviews with informants from the Department of Education, that for equivalency for package A and B participatory learners are very good, this is evidenced by the many workers dropouts have managed to follow the packet., While the participation to follow the package $\mathrm{C}$ is still lacking, many influencing factors, among others; a lack of support from parents, who think that education 
is not very important, because in the neighborhood, there are some educated quite nice but hard to get a job and ended up working in the industry in which their children to work, so that his or her status at the workers. And with education can improve aspects of affective, cognitive and psychomotor. In addition to these programs, there are still other programs targeting child labor that is the School Operational Assistance (BOS), Bea poor rest (BSM), and Family Program (PKH), the programs mentioned above are a solution to reduce the number of child workers.

Therefore, to break the chain of poverty is to provide education and adequate training, as proposed by Adesina (2010) that, in order to overcome poverty and eliminate child labor can be done with a model of multi-pillar, which means that in order to eliminate child labor programs that there should have been done in a coordinated manner and required commitment from the region, it is intended that activity programs can be sustainable.

All this has a lot of programs in the form of assistance with the aim that the children go back to school, but in reality the implementation of government assistance is often less effective, this is due to an interagency or the ministry has a program similar runs each, with no coordination so the result is less than optimal.

Actually, the contribution of child labor to the family economy is not significant. That is, although the child workers earn, but economic conditions remain poor families. Therefore, to overcome the problem of child labor, should also be empowered his family, economically empowered to reduce the number of child workers. Related to empowering families, many governments have implemented programs, such as by lending capital, skills training in entrepreneurship, but until now these programs are less effective.

Child protection policy towards tackling child labor was considered not effective. It is caused by various obstacles. Among other things, social values such as historical values, traditions, customs, social, cultural society composed of patterned behavior, and weak monitoring system conducted by the field of labor inspection from the Department of Manpower and Transmigration. Therefore, prevention of child labor more emphasized in the Ministry of Home Affairs and Regional Autonomy No. 5 of 2001, dated January 8, 2001, on Combating Child Labor, described in article 1, paragraph 4, that the Combating Child Labor or the so-called PPA is an activity undertaken to remove, reduce and protect child workers aged 15 years and under to avoid the adverse effects of heavy and dangerous work. While the implementation of the PPA can be done by the Government, local government, Universities, Community Institutions and other institutions that care about child labor.

Social protection child labor is not something that can be done easily and quickly but requires a long process and the participation of all elements of society, and should be conducted with the cooperation between central and local government, and the extent to which the State has to provide protection against child labor, Issues relating to the elimination of child labor, main responsibility is to formulate a social protection strategy rests with the government, however, organizations of workers and employers also have an important role. Social partners can help the government in integrating social protection programs, so that the objectives and targets can be achieved.

\section{CONCLUSION}

Based on the results of research and exposure of the description in the discussion above, it can be summed up some of the following:

1. Child labor in the study area the majority of low educational background, and come from poor families number of rules that have been passed related to social protection for child workers, however, the protection process is still not optimal. Implementation is done by each department or ministry, giving the impression of overlap between one program to another program, and there is no coordination between agencies. So the result is less effective. 
2. Factors which could hamper the implementation of social protection which is a limited budget, understaffed courts, a lack of support from the families of young workers and entrepreneurs.

\section{ACKNOWLEDGEMENT}

Thanks to those who helped in conducting research until I could pour it in this paper.

\section{REFERENCES}

Adesina, Jimi O. (2010). Rethinking The Social Protection Paradism. Organised by The European Report of Development in Dakar. Sinegal.

Bhalotra, S., and C. Heady. (2003). Child Farm Labor: The Wealth Paradox. World Bank Economic Review, 17(2), pp. 197-227.

Chambers, D. (2000). Social policy and Social Program. Third Edition. Allyn and Bacon. Boston.

Suyanto, B .(2003). pekerja Anak dan kelangsungan pendidikannya. Airlangga University Press. Surabaya

Badan Pusat Statistik (BPS) - ILO. (2015) Kemiskinan di Indonesia. Jakarta

Undang-undang Republik Indonesia, No 4 Tahun 1979 tentang Kesejahteraan Anak. Jakarta.

Keputusan Menteri Dalam Negeri Dan Otonomi Daerah Nomor 5 Tahun 2001, tanggal 8 Januari 2001, tentang Penanggulangan Pekerja Anak. Jakarta

http//mcrizzwan blogspot.co.id/2015/02/artikel aturanaturan dan perlindungan. diakses pada tanggal 14 februari 2017. http://www.maschun.com/2015/09/bpsbadan Pusat Statistik. 2015. Kemiskinandi.html. diakses tgl 2/6/16/jam 15.30 